\title{
Enhancement of cumulus expansion and nuclear maturation during bovine oocyte maturation in vitro by the addition of epidermal growth factor and insulin-like growth factor I
}

\author{
P. L. Lorenzo, M. J. Illera, J. C. Illera and M. Illera* \\ Departamento de Fisiología Animal, Facultad de Veterinaria, Universidad Complutense de Madrid, \\ Ciudad Universitaria 28040, Madrid, Spain
}

\begin{abstract}
This study was carried out to identify the possible effects of epidermal growth factor (EGF) and insulin-like growth factor-I (IGF-I) on cumulus expansion and nuclear maturation in bovine oocytes matured in vitro in serum-free media. Bovine follicular oocytes were matured in vitro and were then classified as cumulus cell-enclosed oocytes or denuded oocytes. They were then cultured for $24 \mathrm{~h}$ in TCM-199 (tissue culture medium-199) with EGF (50 ng $\mathrm{ml}^{-1}$ ), IGF-I (100 $\mathrm{ng} \mathrm{ml}^{-1}$ ) and EGF plus IGF-I (50 and $100 \mathrm{ng} \mathrm{ml}^{-1}$, respectively). At the end of the culture period, the morphology of oocytes was evaluated for cumulus expansion and nuclear stage of maturation. In Expt 1 , percentages of oocytes reaching maximum cumulus expansion were: $12.5 \%$ (control), $46.5 \%$ (EGF), $15.2 \%$ (IGF-I) and $52.8 \%$ (EGF plus IGF-I). In Expt 2, the respective rates of nuclear maturation were: $35.6 \%, 52.1 \%, 45.5 \%$ and $61.4 \%$ for cumulus cell-enclosed oocytes, and $35.3 \%, 46.6 \%, 45.4 \%$ and $42.5 \%$ for denuded oocytes; the same growth factor treatments were used in both cases. There was no significant effect of IGF-I on cumulus expansion. Maximum rates of cumulus expansion and nuclear maturation were obtained in the presence of both growth factors. These results lead to the following conclusions: (i) EGF, either alone or together with IGF-I, stimulates cumulus expansion; and (ii) both growth factors, acting alone or together, enhance nuclear maturation in oocytes surrounded by compact cumulus cells.
\end{abstract}

\section{Introduction}

Bovine oocytes mature in vivo at the time of the pre-ovulatory gonadotrophin surge, but can also mature in vitro in a suitable medium (Edwards, 1965). The maturation depends on the interaction of many factors and enables oocyte development to reach metaphase II (Tonetta and DiZerega, 1989). A more detailed study of conditions that are necessary for maturation in vitro is required.

Gonadotrophins are the primary regulators of nuclear maturation in mammalian oocytes in vivo. However, more recent observations imply that gonadotrophin is only one of a complex sequence of factors, such as growth factors, that appear to regulate ovarian function. Epidermal growth factor (EGF) stimulates ovarian granulosa cell proliferation in vitro in various species (Gospodarovicz and Bialecki, 1979; May et al., 1987), modulates granulosa cell differentiation (Hsueh et al., 1981) and stimulates the growth of small follicles in women (Westergaard et al., 1990). It appears that EGF, like LH, promotes oocyte maturation by disrupting its communication with cumulus cells (Dekel and Sherizly, 1985) or that it creates a positive maturation signal (Downs, 1989). Insulin-like growth factor I (IGF-I) is a potent mitogen for granulosa cells

${ }^{*}$ Correspondence.

Received 17 January 1994.
(Hernández et al., 1988), even in the absence of FSH (Veldhuis et al., 1986), and acts as a biological amplifier of the action of FSH in the ovary (Hsu and Hammond, 1987). With respect to the maturation of oocytes in vitro, as yet undefined follicular factors influence oocyte maturation (Tonetta and DiZerega, 1989). Herlerr et al. (1992) showed that addition of IGF-I to maturation medium improves the quality of bovine embryos. Identification of these 'follicular factors' would contribute to the knowledge of intrafollicular regulation of oocyte maturation.

The aim of the present study was to establish whether EGF and IGF-I, alone and in combination, added to serum-free maturation media without addition of exogenous hormones enhance the cumulus expansion and the maturation rate of bovine oocytes in vitro.

\section{Materials and Methods}

All reagents and media were purchased by Sigma Chemical Co. (St Louis, MO) except IGF-I (Boehringer Mannheim GmbH, Mannheim). Ovaries were obtained from an abattoir and were transported to the laboratory in PBS (Dulbecco) at $39^{\circ} \mathrm{C}$ within $1 \mathrm{~h}$. Contents of small visible antral follicles $(2-8 \mathrm{~mm}$ in diameter) were aspirated with an 18-gauge needle attached to a $10 \mathrm{ml}$ disposable syringe, and placed in conical tubes kept at 
Table 1. Effect of growth factors on cumulus expansion of bovine oocytes matured in vitro

\begin{tabular}{lcccccc}
\hline & \multicolumn{5}{c}{ Cumulus expansion } \\
\cline { 2 - 7 } Treatment & $\begin{array}{c}\text { Number of } \\
\text { oocytes }^{\mathrm{a}}\end{array}$ & $\begin{array}{c}0 \\
(\%)\end{array}$ & $\begin{array}{c}+ \\
(\%)\end{array}$ & $\begin{array}{c}++ \\
(\%)\end{array}$ & $\begin{array}{c}+++ \\
(\%)\end{array}$ & $\begin{array}{c}\text { LS Means* } \\
( \pm \text { SEM) }\end{array}$ \\
\hline Control & 80 & 67.5 & 12.1 & 7.6 & 12.5 & $0.65 \pm 0.14^{\mathrm{b}}$ \\
EGF & 92 & 22.8 & 18.4 & 12.3 & 46.5 & $1.86 \pm 0.13^{\mathrm{c}}$ \\
IGF-I & 87 & 34.4 & 30.3 & 20.7 & $1.12 \pm 0.14^{\mathrm{b}}$ \\
EGF+ IGF-I & 91 & 15.3 & 12.1 & 18.6 & 52.8 & $2.11 \pm 0.13^{\mathrm{c}}$ \\
\hline
\end{tabular}

${ }^{2}$ Data pooled from five independent experiments.

Cumulus expansion -0 : no detectable response equals $0 ;+$ : minimum observable response equals $1 ;++$ : moderate response equals 2 , and +++ indicates the maximum degree of cumulus expansion equals 3 .

${ }^{*}$ LS Means ( \pm SEM) with different superscripts are significantly different, ${ }^{b}$ versus ${ }^{c} P<0.05$.

$39^{\circ} \mathrm{C}$. After $30 \mathrm{~min}$, the sedimented oocytes were transferred to a $35 \mathrm{~mm}$ plastic Petri dish containing $2 \mathrm{ml}$ of Hepes-buffered washing medium (TCM $199+2 \%$ fetal calf serum (FCS)) and given five washes.

Selected oocytes (with homogeneous and evenly granulated cytoplasm) were divided into cumulus cell-enclosed (with intact and unexpanded cumulus) and denuded oocytes (without layers of cumulus cells) according to a previous criteria (Lorenzo et al., 1992). These were placed into drops $(50 \mu \mathrm{l})$ of maturation medium under oil, and cultured in $35 \mathrm{~mm}$ Petri dishes at $39^{\circ} \mathrm{C}$ in air with $5 \% \mathrm{CO}_{2}, 95 \%$ humidity for $24 \mathrm{~h}$. The oocytes (five per drop) were matured in TCM-199 with the addition of L-glutamine and sodium bicarbonate. Growth factors were added to the maturation media; there were four different treatments: control, EGF $\left(50 \mathrm{ng} \mathrm{ml}^{-1}\right)$, IGF-I (100 ng $\mathrm{ml}^{-1}$ ) and EGF plus IGF-I (50 and $100 \mathrm{ng} \mathrm{ml}^{-1}$, respectively). Except in the case of the isolation medium no serum source was used in the maturation media.

In Expt 1, cumulus-oocyte complexes were evaluated at the end of the culture period to assess the effect of growth factors on cumulus cell expansion. The criteria used for describing cumulus expansion was a subjective scoring system in which: 0 indicated no detectable response; + indicated the minimum observable response and +++ indicated the maximum degree of expansion, where all layers of cumulus cells expanded, even those closest to the oocyte.

At the end of the culture period in Expt 2, the oocytes were fixed to ascertain the influence of growth factors on nuclear maturation in vitro and the effect of the presence or absence of cumulus cells around the oocyte. Cumulus cell-enclosed and denuded oocytes were used. Cumulus cells of the latter group were removed with hyaluronidase $\left(200 \mathrm{U} \mathrm{ml}^{-1}\right)$ and mechanically stripped. The oocytes were then pipetted onto a slide. A coverslip spotted with a paraffin wax:vaseline (10:1) mixture at each corner was placed directly over the centre of the drop containing the oocytes. Fixation of oocytes was carried out by placing the slides in acetic acid:ethanol $(\mathrm{I}: 3, \mathrm{v}, \mathrm{v})$ for $24 \mathrm{~h}$ and staining with a drop of aceto-orcein $(2 \%$ orcein in $60 \%$ acetic acid) for $2 \mathrm{~min}$, followed by washing under tap water. Nuclear maturation was evaluated and classified as germinal vesicle (GV), metaphase I (M I), including metaphase I, anaphase I and telophase I, metaphase II (M II) and degenerate.

\section{Statistical analysis}

The degree of cumulus expansion in Expt 1, and metaphase II stage in both groups of oocytes in Expt 2, were used as endpoint parameters for assessing the effect of growth factor on expansion and maturation of bovine oocytes in vitro. Statistical analysis of endpoints was carried out by using the Biomedical Data Program (BMDP, Dixon et al., 1990). Expts I and 2 were repeated (groups of oocytes were processed on different occasions) five and seven times, respectively. Cumulus expansion at the end of the culture period was assigned a numerical value corresponding to the degree of expansion achieved, where minimum response $(+)$ equals $I$, moderate response $(++)$ equals 2 , and maximum response equals 3 . These numerical scores were subjected to analysis of variance using the $7 \mathrm{~d}$ procedure of BMDP. The data $(n=350$ cumulus cellenclosed oocytes) were analysed by replication $(n=5)$ and treatments $(n=4)$. Comparisons between least square means (LS \pm SEM) were made by $t$ test. Mean values for Expt 2 $(n=914)$ were compared by a variance analysis ( $7 \mathrm{~d}$ procedure of BMDP), and differences between individual means were analysed by pairwise $t$-test and Bonferroni post-test to determine whether values were statistically different. A $P$ value $<0.05$ was accepted as denoting significant differences between groups.

\section{Results}

A total of 1264 bovine oocytes were used and evaluated in this study. In Expt I $(n=350)$, the respective data of cumulus cell-enclosed oocytes that attained cumulus expansion (\% expansion +++ and LS means \pm SEM) in the four different treatments, were: $12.5 \%$ and $0.65 \pm 0.14$ (control), $46.5 \%$ and $1.86 \pm 0.13$ (EGF), $15.2 \%$ and $1.12 \pm 0.14$ (IGF-I) and $52.8 \%$ and $2.11 \pm 0.13$ (EGF + IGF-I) (Table 1). Treatment with EGF resulted in a significantly higher incidence $(P<0.05)$ of cumulus expansion compared with control and IGF-I treatment. When EGF was used together with IGF-I, cumulus expansion was greater than for treatment with IGF-I alone $(P<0.05)$. No significant effect was observed after treatment with IGF-I compared with control treatment. 
Table 2. Nuclear stages of bovine cumulus-cell enclosed oocytes on maturation in vitro with growth factors

\begin{tabular}{|c|c|c|c|c|c|}
\hline Treatment & $\begin{array}{l}\text { Number of } \\
\text { oocytes }^{a}\end{array}$ & Degenerate & Germinal vesicle & Metaphase I & Metaphase II \\
\hline Control & 96 & $16.0 \pm 3.1$ & $24.9 \pm 6.0$ & $22.7 \pm 3.5$ & $35.6 \pm 3.3^{\mathrm{b}}$ \\
\hline EGF & 128 & $9.3 \pm 1.2$ & $6.7 \pm 1.0$ & $31.9 \pm 2.9$ & $52.1 \pm 4.7^{c}$ \\
\hline IGF-I & 105 & $13.3 \pm 2.1$ & $7.7 \pm 3.3$ & $29.3 \pm 3.7$ & $49.5 \pm 3.1^{\mathrm{c}}$ \\
\hline $\mathrm{EGF}+\mathrm{IGF}-\mathrm{I}$ & 141 & $5.9 \pm 2.1$ & $3.0 \pm 1.4$ & $29.8 \pm 4.3$ & $61.4 \pm 3.6^{\mathrm{d}}$ \\
\hline
\end{tabular}

Values are percentages \pm SEM.

${ }^{a}$ Data pooled from seven independent experiments.

Values within column with different superscripts are significantly different.

${ }^{b}$ versus ${ }^{c} P<0.05 ;{ }^{b}$ versus ${ }^{d} P<0.01 ;{ }^{c}$ versus ${ }^{d} P<0.05$.

Table 3. Nuclear stages of bovine denuded oocytes on maturation in vitro with growth factors

\begin{tabular}{lccccc}
\hline Treatment & $\begin{array}{c}\text { Number of } \\
\text { oocytes }^{\mathrm{a}}\end{array}$ & Degenerate & Germinal vesicle & Metaphase I & Metaphase II \\
\hline Control & 69 & $21.9 \pm 3.4$ & $15.8 \pm 4.1$ & $28.1 \pm 3.1$ & $35.3 \pm 6.1^{\mathrm{b}}$ \\
EGF & 117 & $15.7 \pm 1.9$ & $10.0 \pm 2.7$ & $28.8 \pm 1.2$ & $46.6 \pm 4.0^{\mathrm{b}}$ \\
IGF-I & 114 & $14.8 \pm 1.8$ & $15.5 \pm 1.3$ & $25.3 \pm 2.5$ & $44.4 \pm 4.9^{\mathrm{b}}$ \\
EGF + IGF-I & 144 & $12.8 \pm 1.2$ & $6.2 \pm 1.1$ & $40.5 \pm 4.9$ & $42.5 \pm 2.7^{\mathrm{b}}$ \\
\hline
\end{tabular}

Values are percentages \pm SEM.

${ }^{a}$ Data pooled from seven independent experiments.

Values within column with the same superscript are not significantly different.

In Expt $2(n=914)$, maturation rates obtained for the four treatments with cumulus cell-enclosed oocytes $(n=470)$, were: $35.6 \%$ (control), $52.1 \%$ (EGF), $49.5 \%$ (IGF-I) and $61.4 \%$ (EGF + IGF-I) (Table 2), while the rates for denuded oocytes were $35.3 \%, 46.6 \%, 44.4 \%$ and $42.5 \%$, respectively (Table 3 ). In cumulus cell-enclosed oocytes, statistically significant differences in the metaphase II stage were observed between: control and EGF treatment $(P<0.05)$, control and IGF-I treatment $(P<0.05)$, control and EGF + IGF-I treatment $(P<0.01)$. The highest metaphase II values were recorded for treatment with EGF + IGF-I. Moreover, compared with IGF-I or control treatments, this treatment resulted in significant differences in the metaphase II stage $(P<0.05$ and $P<0.01$, respectively).

There were no significant differences in the maturation rate for denuded oocytes ( $n=444$ ) among the four treatments used (Table 3).

\section{Discussion}

Cumulus oophorus expansion in bovine oocytes occurs in response to an ever-changing milieu of gonadotrophins, growth factors, steroids, factors secreted by the oocyte, and other unknown molecules (Buccione ef al., 1990). These compounds could be contributing to maturational changes that occur in the oocyte (Hyttel et al., 1989), mediated by intracellular messengers such as CAMP, calmodulin or diacylglycerol (Gonçalves and Graves, 1992). A similar expansion criterion was adopted in the study reported here to those used by Behnke, (1987) and Downs (1989), but the results recorded for cumulus expansion in control medium (in the absence of growth factors) were also similar to those of other authors who used similar conditions (Hensleigh and Hunter, 1985; Younis et al., 1989), probably because of the absence in the maturation media of serum, hormones and other factors.

Serum-free media was used for maturation in vitro in an attempt to determine the relationship between growth factors and the regulation of nuclear maturation and cumulus expansion, while effectively ruling out the influence of unknown serum factor(s). It has been demonstrated that these growth factors can be synthesized by the ovary (May et al., 1987). The presence of EGF or EGF-like substances has been demonstrated for porcine and human follicles at concentrations similar to those used in the study reported here (Hsu et al., 1987; Hoffman et al., 1990). Moreover, concentrations of IGF-I, similar to those used in the present study, have been detected in bovine and porcine follicular fluid (Hammond et al., 1988; Echternkamp et al., 1990).

The results indicate that EGF enhances cumulus expansion in bovine cumulus-oocyte complexes, in the same way as demonstrated by Downs (1989) for rodent oocytes. IGF-I cannot promote effective cumulus expansion, probably because it does not act via the cumulus cells, or because it interferes with the production of an 'expansion factor' produced by the oocyte (Buccione et al., 1990). Zhang et al. (1991) used IGF-I analogues, such as insulin and they too reported poor results for bovine cumulus expansion. We demonstrated that EGF stimulates 
resumption of meiosis in bovine oocytes in the absence of serum or hormones. Our data are in agreement with the results obtained for germinal vesicle breakdown in rodent oocytes (Dekel and Sherizly, 1985; Downs, 1989), as well as those obtained in bovine oocytes (Sanbuissho et al., 1990) and porcine oocytes (Reed et al., 1993).

The effects of the growth factors on nuclear maturation are different where each alone stimulates maturation, although the highest results were achieved with the addition of EGF plus IGF-I. This finding could indicate an additive action between the growth factors used and indicates that their actions are combined under conditions in vivo. When added to the maturation media, EGF plus IGF-I significantly enhanced nuclear maturation in vitro in bovine oocytes and they brought about specific actions on oocyte maturation, including cumulus and cytoplasmic effects. Hainaut et al. (1991) postulated that maturation with IGF-I is initiated upon activation of the membrane receptor for this growth factor and requires tyrosine dephosphorylation of $\mathrm{p} 34$, the kinase component of maturation promoting factor (MPF).

The growth factors used in the study reported here enhanced maturation in cumulus-oocyte complexes but not in denuded oocytes, and this was in accordance not only with the results observed in cattle (Sanbuissho et al., 1990; Lorenzo et al., 1992) and rodents (Deckel and Sherizly, 1985; Downs, 1989), but also with those obtained using TGF- $\alpha$, which has similar effects to EGF in vitro (Brucker et al., 1991), and binds to the same receptor species (Massagué, 1983; Derynck, 1986). Our hypothesis is that the growth factors act in the presence of the cumulus cells, via which a positive stimulus for maturation is transferred to the oocyte. This stimulatory signal promotes oocyte maturation and can subsequently also disrupt oocyte communication with the cumulus cells, according to a study conducted by Deckel and Sherizly (1985). The growth factors in follicular fluid may be a key factor in the regulation of intrafollicular bovine oocyte maturation. The role of IGF-I may be subtle in cytoplasmic maturation, evincing its positive effect only in fertilization or early events related to embryogenesis (Herlerr et al., 1992).

It is feasible too that EGF plus IGF-I interact with gonadotrophins, steroids or other molecules to regulate oocyte follicular development in vivo. In conclusion, we provided evidence that EGF, either alone or in conjunction with IGF-I, stimulates cumulus expansion. The addition of EGF, IGF-I or both factors enhanced nuclear maturation in immature bovine oocytes in vitro and this effect is mediated by the presence of cumulus cells. These findings may explain the mechanism of agents involved in the generation of signals regulating the oocyte maturation process. Research into the effect of growth factors on bovine IVF is currently under way.

The authors thank P. Jiménez of the GYPISA abattoir and T. Calduch, for technical assistance in this study, and F. Pescador of the Computer Science Department (Complutense University of Madrid, Spain) for help with statistical analysis.

\section{References}

Behnke JE (1987) Bovine Sperm Capacitation and Oocyte in vitro Maturation. $\mathrm{PhD}$ Thesis, Minnesota University
Brucker C, Alexander NJ, Hodgen GD and Sandow BA (1991) Transforming growth factor- $\alpha$ augments meiotic maturation of cumulus cell-enclosed mouse oocytes Molecular Reproduction and Development 28 94-98

Buccione R, Vanderhyden BC, Caron PJ and Eppig JJ (1990) FSH-induced expansion of the mouse cumulus oophorus in vitro is dependent upon a specific factor(s) secreted by the oocyte Developmental Biology 138 I6-25

Dekel N and Scherizly I (1985) Epidermal growth factor induces maturation of rat follicle enclosed oocytes Endocrinology 116 512-516

Derynck R (1986) Transforming growth factor- $\alpha$ : structure and biological activities Journal of Cell Biochemistry 32 293-304

Dixon WJ, Brown MB, Engelman L, Hill MA and Jennrich RI (1990) BMDP Statistical Software Manual. University of California Press, Los Angeles

Downs SM (1989) Specificity of epidermal growth factor action on maturation of the murine oocyte and the cumulus oophorus in vitro Biology of Reproduction 41 371-379

Echternkamp SE, Spicer LJ, Gregory KE, Channing SF and Hammond JM (1990) Concentrations of insulin-like growth factor-I in blood and ovarian follicular fluid of cattle selected for twins Biology of Reproduction 43 8-14

Edwards RG (1965) Maturation in vitro of mouse, sheep, cow, pig, rhesus monkey and human ovarian oocytes Nature 208 349-351

Gonçalves PB and Graves CN (1992) Interaction between CAMP, diacylglycerol and $\mathrm{Ca}^{2+}$-calmodulin pathways in the regulation of cumulus expansion Biology of Reproduction 46 (Supplement 1) 69

Gospodarowicz D and Bialecki H (1979) Fibroblast and epidermal growth factors are mitogenic agents for cultured granulosa cells of rodent, porcine and human origin Endocrinology 104 757-764

Hainaut P, Giorgetti S, Kowlaski A, Ballotti R and Van Obberghen E (1991) Antibodies to phosphotyrosine injected to Xenopus laevis oocytes modulate maturation induced by insulin/IGF-I Experimental Cell Research 195 129-136

Hammond JM, Hsu CJ, Klindt J, Tsang BK and Downey BR (1988) Gonadotropins increase concentrations of immunoreactive insulin-like growth factor-I in porcine follicular fluid in vivo Biology of Reproduction 38 304-308

Hensleigh HC and Hunter AG (1985) In vitro maturation of bovine cumulus enclosed primary oocytes and their subsequent in vitro fertilization and cleavage Journal of Dairy Science 68 1456-1562

Herlerr A, Lucas-Hann A and Niemann A (1992) Effects of insulin-like growth factor-I on in vitro production of bovine embryos Theriogenology 37 1213-1224

Hernández ER, Resnick CE, Svoboda ME, Van Wyk JJ, Payne DW and Adashi EY (1988) Somatomedin-C/insulin-like growth factor I as an enhancer of androgen biosynthesis by cultured rat ovarian cells Endocrinology 122 1603-1612

Hoffmann GE, Scott RT, Jr, Brzyski RG and Jones HW, Jr (1990) Immunoreactive epidermal growth factor concentration in follicular fluid obtained from in vitro fertilization Fertility and Sterility $\mathbf{5 4} 303-307$

Hsu C and Hammond JM (1987) Gonadotropins and estradiol stimulate immunoreactive insulin-like growth factor-I production by porcine cells in vitro Endocrinology 120 198-207

Hsu CJ, Holmes SD and Hammond JM (1987) Ovarian epidermal growth factor-like activity: concentrations in porcine follicular fluid during follicular enlargement Biochemical and Biophysical Research Communications 147 242-247

Hsueh AJW, Welsh TH and Jones PBC (1981) Inhibition of ovarian and testicular steroidogenesis by epidermal growth factor Endocrinology 108 2002-2004

Hyttel P, Greve T and Callesen H (1989) Ultrastructural aspects of oocyte maturation and fertilization in cattle Journal of Reproduction and Fertility Supplement 38 35-47

Lorenzo P, Illera MJ, Sánchez J, Silván G and Illera JC (1992) The effect of EGF on cumulus expansion and bovine oocyte maturation in vitro Theriogenology 37250

Massagué J (1983) Epidermal growth factor-like transforming growth factor II. Interaction with epidermal growth factor receptor in human placenta membranes and A431 cells Journal of Biological Chemistry 258 1361413620

May JV, Buck PA and Shomberg DW (1987) Epidermal growth factor enhances ${ }_{125}^{125}$ Iodo-follicle stimulating hormone binding by cultured porcine granulosa cells Endocrinology $1202413-2420$

Reed ML, Estrada JL, Illera MJ and Petters RM (1993) Effects of epidermal growth factor, insulin-like growth factor-I, and dialyzed porcine follicular fluid on porcine oocyte nuclear maturation in vitro Journal of Experimental Zoology 266 74-78

Sanbuissho A, Coskum S and Lin YC (1990) Stimulatory action of epidermal growth factor (EGF) on in vitro bovine oocyte maturation Assisted Reproduction Technology and Andrology 1 143-153 
Tonetta SA and DiZerega GS (1989) Intragonadal regulation of follicular maturation Endocrine Reviews 10 205-229

Veldhuis JD, Rodgers RJ and Furlanetto RW (1986) Synergistic actions of estradiol and the insulin-like growth factor somatomedin-C on swine ovarian (granulosa) cells Endocrinology 119 530-538

Westergaard LG, Andersen CY and Byskov AG (1990) Epidermal growth factor (EGF) in small antral ovarian follicles of pregnant women Journal of Endocrinology $127 \quad 363-367$
Younis AI, Brackett BG and Fayrer-Hosken RA (1989) Influence of serum and hormones on bovine oocyte maturation and fertilization in vitro Gamete Research 23 189-201

Zhang L, Blakewood EG, Deninston RS and Godke RA (1991) The effect of insulin on maturation and development of in vitro-fertilized bovine oocytes Theriogenology 35301 